\title{
Teaching NeuroImages: Migrating sparganum captured on brain MRI
}

Zhenwen Yan, MD, PhD, and Meiguang Zheng, MD

Neurology ${ }^{\circledR}$ 2019;92:e1143-e1144. doi:10.1212/WNL.0000000000007046

A 16-year-old girl presented with repeated seizure, headache, and vomiting. One year after symptom onset, MRI revealed a midbrain lesion (figure 1). Symptoms persisted despite antituberculosis treatment. Repeat MRI 1 year later showed lesion of similar size/shape, but shifted by $1.4 \mathrm{~cm}$. Spirometra mansoni antibody was positive in serum and CSF. Sparganosis was verified upon surgery (figure 2). Symptoms disappeared after surgery, and she was discharged. Key features indicative of sparganosis in this case included migrating lesion and positive antibody. Definitive diagnosis requires recovery of sparganum from the lesion. ${ }^{1}$ Surgery provides a cure; pharmacotherapy is typically ineffective. ${ }^{2}$

\section{Author contributions}

Z. Yan: study design and manuscript writing. M. Zheng: study design and surgery.

\section{Study funding}

No targeted funding reported.

\section{Disclosure}

The authors report no disclosures relevant to the manuscript. Go to Neurology.org/ $\mathrm{N}$ for full disclosures.

\section{References}

1. Liao H, Li D, Zhou B, et al. Imaging characteristics of cerebral sparganosis with live worms. J Neuroradiol 2016;43:378-383.

2. Kim DG, Paek SH, Chang KH, et al. Cerebral sparganosis: clinical manifestations, treatment, and outcome. J Neurosurg 1996;85: 1066-1071.

\section{Correspondence}

Dr. Yan

yanzhw@mail.sysu.edu.cn

\section{MORE ONLINE}

$\rightarrow$ Teaching slides

links.lww.com/WNL/

A828 

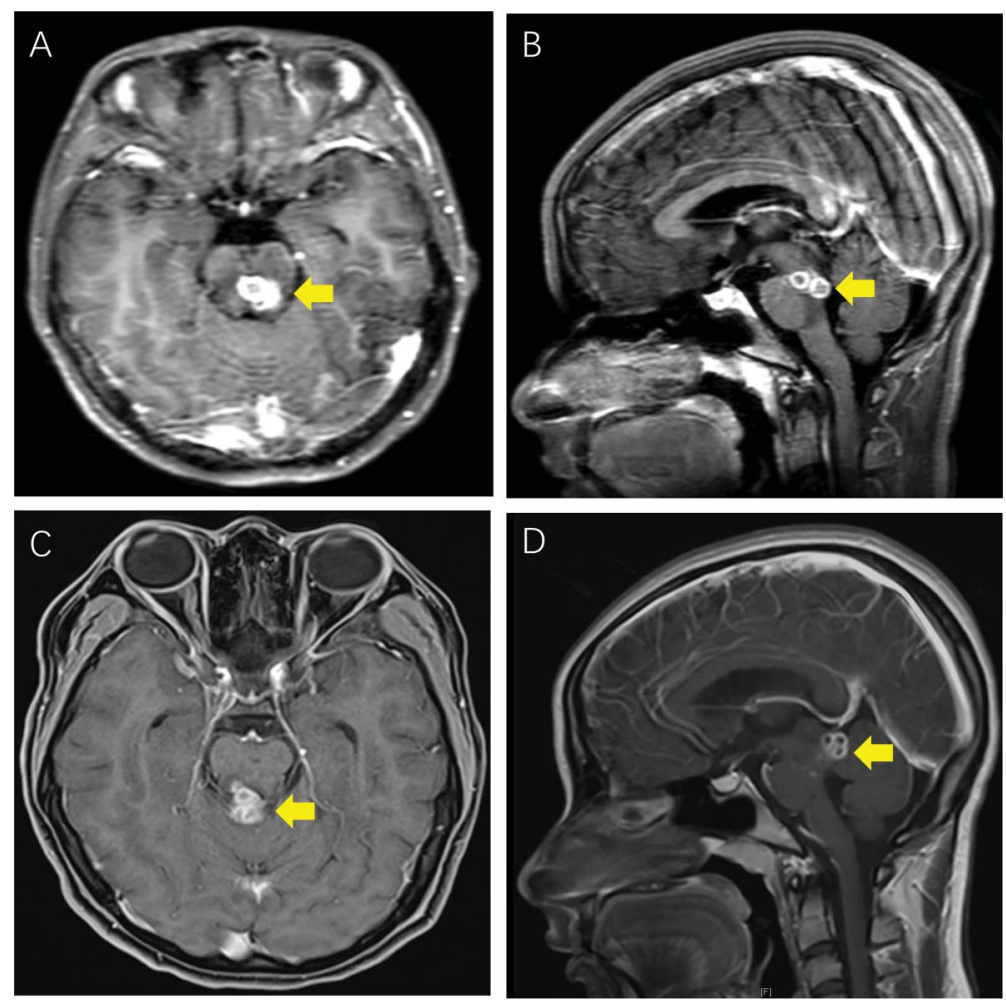

(A, B): 1 year after symptom onset; $(C, D): 2$ years after symptom onset. Arrows indicate lesion site.

Figure 2 Sparganum retrieved by surgery and hematoxylin \& eosin (H\&E) staining of the lesion

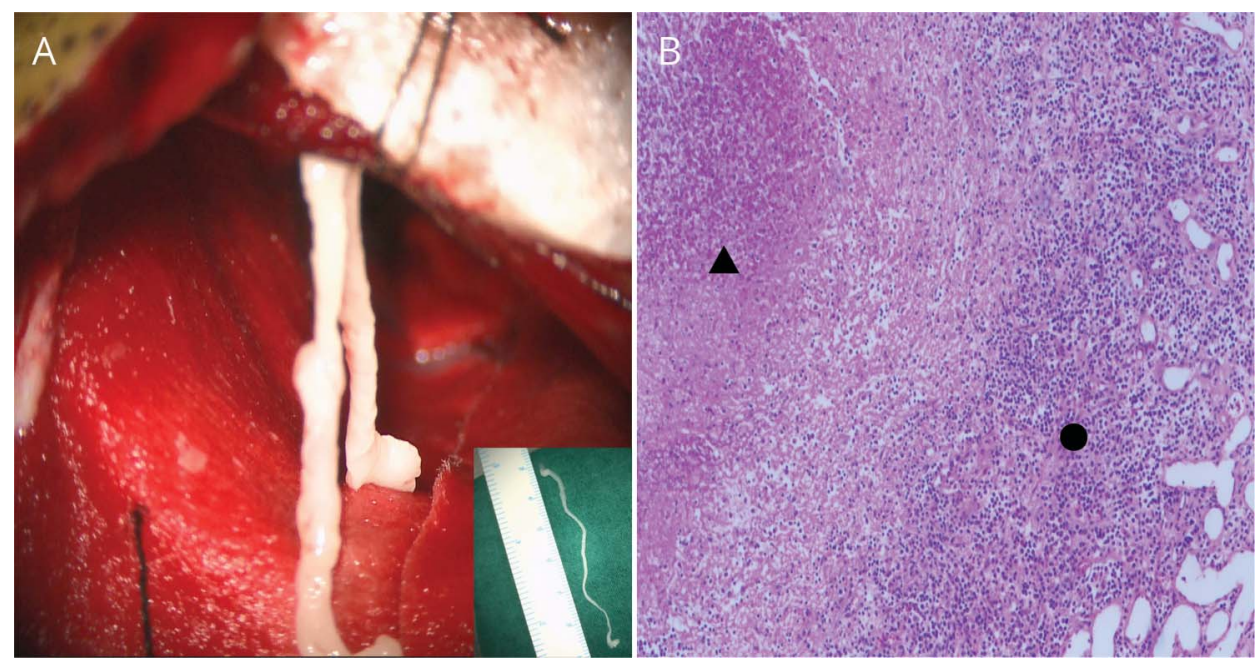

(A) A ribbon-like live worm removed by surgery, measuring $7 \mathrm{~cm}$ in length and $1.2 \mathrm{~mm}$ in width. (B) H\&E staining $(\times 40)$ shows central necrosis $(\boldsymbol{A})$ with lymphocytic and eosinophilic cell infiltration $(\bullet)$ in the periphery of the lesion. 


\section{Neurology}

\section{Teaching NeuroImages: Migrating sparganum captured on brain MRI Zhenwen Yan and Meiguang Zheng \\ Neurology 2019;92;e1143-e1144 \\ DOI 10.1212/WNL.0000000000007046}

\section{This information is current as of March 4, 2019}

\section{Updated Information \& Services}

References

Subspecialty Collections

Permissions \& Licensing

\section{Reprints}

including high resolution figures, can be found at: http://n.neurology.org/content/92/10/e1143.full

This article cites 2 articles, 0 of which you can access for free at: http://n.neurology.org/content/92/10/e1143.full\#ref-list-1

This article, along with others on similar topics, appears in the following collection(s):

All Infections

http://n.neurology.org/cgi/collection/all_infections

CME

http://n.neurology.org/cgi/collection/cme

MRI

http://n.neurology.org/cgi/collection/mri

Information about reproducing this article in parts (figures,tables) or in its entirety can be found online at:

http://www.neurology.org/about/about_the_journal\#permissions

Information about ordering reprints can be found online:

http://n.neurology.org/subscribers/advertise

Neurology ${ }^{\circledR}$ is the official journal of the American Academy of Neurology. Published continuously since 1951, it is now a weekly with 48 issues per year. Copyright @ 2019 American Academy of Neurology. All rights reserved. Print ISSN: 0028-3878. Online ISSN: 1526-632X.

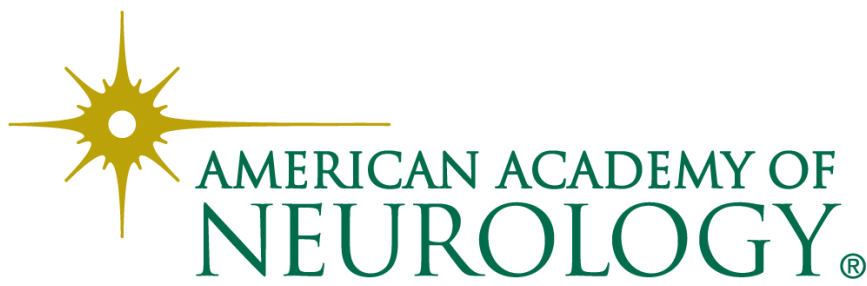

